\title{
Tras las hUEllas de UNA TRAdición: \\ LA Virgen de Izamal en Yucatán. Historia, CAMBIOS, PERMANENCIAS Y ADAPTACIONES DE UNA IMAGEN DE DEVOCIÓN
}

\section{In the Footsteps of Tradition: The Izamal Virgin. History, Changes, Continuity and Adaptations OF AN IMAgE OF DEVOTION}

\section{Bertha Pascacio Guillén ${ }^{1}$}

Resumen: Las imágenes devocionales están rodeadas de tradiciones y leyendas que validan su importancia, función y el papel sociocultural que juegan dentro de las sociedades que las custodian. El caso de la Virgen de Izamal, la imagen de mayor devoción en la península yucateca, no es la excepción; esta efigie que generó un culto de gran importancia desde finales del siglo XVI hasta nuestros días ha atravesado junto con el pueblo yucateco una serie de vicisitudes ante las cuales se ha ido adaptando, reinventando y transformando. Esto ha creado a su alrededor una serie de leyendas que nos permiten conocer la forma en que una imagen de devoción proporciona una respuesta social y psicológica que la lleva a convertirse en un icono de larga duración.

Palabras clave: devoción, imagen de culto, religiosidad, respuesta psicológica.

\footnotetext{
${ }^{1}$ Maestra en historia del arte; actualmente cursa el doctorado en historia del arte. Profesora de asignatura en la Escuela Nacional de Antropología e Historia. Temas de investigación: imágenes devocionales y arte sacro en la península de Yucatán.

Correo electrónico: sakilja@gmail.com

Fecha de recepción: 0710 14; Fecha de aceptación: 250215.
} 
Abstract: Devotion images are surrounded by traditions that validate their importance, function and sociocultural role within societies that guard them. The case of the Virgin of Izamal, with greater devotion in the Yucatan Peninsula, is no exception; this effigy generated an important cult that has spanned from the late sixteenth century to the present day. Among Yucatec people this cult has experienced a series of vicissitudes but has been adapting and transforming; indeed creating a number of legends around it. Now we know how an image of devotion provides a social and psychological response, becoming an icon of long duration.

Keywords: devotion, cult effigy, religion, psychological response.

\section{Introducción}

La península de Yucatán es una región de gran riqueza cultural y religiosa. En los diferentes cultos a las imágenes sacras se pueden observar los matices que reviste la religiosidad popular; son devociones llenas de colorido y folklore que inundan las calles con súplicas, sonrisas, olores y sabores, todo alrededor de una imagen que se piensa y sabe milagrosa, donde las múltiples emociones acompañan a los fieles en su largo peregrinar con la simple finalidad de ver y sentir, de caminar entre los santos, cruces, cristos y vírgenes, para después rememorar durante los trances difíciles el hecho de que se ha estado en contacto con lo divino.

Ello nos lleva a preguntarnos hasta dónde una imagen religiosa provoca o evoca; aunque la respuesta a tal interrogante no es fácil, se puede considerar como una invitación a reflexionar sobre la importancia de estudiar la pervivencia de una imagen de culto activo, ya que al ser esta testigo de los procesos históricos de los hombres dan cuenta de la gran riqueza cultural e ideológica del pueblo que la custodia, llegándose a convertir en símbolo de identidad.

Recordemos que para los diferentes pueblos de la península yucateca, los santos, vírgenes y cristos no son sólo imágenes religiosas adscritas a una iglesia. Para ellos, son entidades cuyos límites van más allá de las 
ermitas, santuarios y templos, son miembros activos del pueblo, los más importantes, a los que se les rinde culto y respeto. No se trata sólo de figuras engalanadas con grandes ropones y suntuosos ornamentos, son considerados "hermanos", "padres" y "madres".

Por ello, el conducir la mirada hacia el estudio de las imágenes de culto nos permite analizarlas como sujetos alrededor de los cuales se crean, crecen, modifican, adaptan y permanecen tanto las devociones como los pueblos. Este interés por los cultos religiosos y el área maya me llevó a estudiar la efigie mariana más importante de la península de Yucatán: Nuestra Señora de Izamal, también conocida por sus devotos como Mama Linda. Un caso interesante del empleo y funcionalidad de una imagen que a partir del último tercio del siglo XVI ha sido objeto de un culto muy importante que abarcó desde la península de Yucatán hasta Tabasco, Chiapas y Guatemala, el cual pervive hasta la actualidad.

\section{La Virgen de Izamal. Historia de una imagen y su pueblo}

Su historia comenzó alrededor de 1560, con base en las crónicas religiosas de Bernardo de Lizana, Francisco Vázquez y Diego López Cogolludo. ${ }^{2}$ Cuentan que en este año fue ordenada por fray Diego de Landa a fray Juan de Aguirre, imaginero de origen español, que en esa época representaba a la naciente escuela de escultura guatemalteca, misma que ańos después cobraría gran prestigio en todo el territorio novohispano (Lizana, 1995). ${ }^{3}$ Se trataba de una imagen de talla entera, con ropaje estofado, de rostro color blanco, algo pálido, muy majestuoso

\footnotetext{
${ }^{2}$ Fray Bernardo de Lizana en su obra Historia de Yucatán. Devocionario de Nuestra Señora de Izamal y conquista espiritual; fray Francisco Vázquez en Crónica de la Provincia del santísimo nombre de Jesús de Guatemala de la orden de N. Seráfico padre San Francisco en el reino de la Nueva España; fray Diego López Cogolludo, quien en su Historia de Yucatán explica que el origen de la imagen se remite a 1561, con la visita de fray Diego de Landa a Guatemala, con motivo de un Capítulo celebrado en esta ciudad.

${ }^{3}$ Cabe aclarar que en el Devocionario de Nuestra Señora de Izamal, Lizana escribe que la imagen de la Virgen es llevada en 1558; en el estudio introductorio de René Acuña, éste nos especifica que el autor tiene numerosos errores en cuanto a las fechas, e incluso López Cogolludo lo corrige en variadas ocasiones. La fecha que se escribe acá es la que se menciona en Don Diego Quijada, alcalde mayor de Yucatán 1561-1565, publicado por Scholes y Adams (1938).
} 
y grave, con advocación de Inmaculada Concepción (Florencia y De Oviedo, 1995), tallada a semejanza de la denominada Virgen del Coro del convento de San Francisco de la ciudad de Antigua Guatemala.

Una efigie que desde antes de su llegada al modesto pueblo de Izamal manifestó su milagrosidad al no permitir que la caja en la que ella viajaba, ni los naturales que la cargaban, se mojaran durante todo el tiempo que duró su traslado a la que sería su casa: Izamal (Lizana, 1995). Aunque en la misma arca fueron dispuestas dos imágenes, una con advocación de Inmaculada Concepción y otra de Nuestra Señora de la Natividad — destinada al convento grande de Mérida-, no se dudó en atribuirle a la de Izamal tales milagros, dejando en claro que de las dos hermanas ella era la que realizaba grandes prodigios (Vázquez, 1944). ${ }^{4}$

Al poco tiempo de su arribo al pequeño pueblo de indios causó tal fervor que se creó un culto caracterizado por grandes peregrinaciones y procesiones realizadas en diferentes épocas del año, a las que asistían gentes de todos los grupos étnicos, clases sociales y regiones geográficas, por lo que pronto decidieron llamarle cariñosamente "Mama Linda", por ser la madre de todos que no hacía distinción al socorrer a los necesitados.

Empero, la importancia de dicha imagen no sólo se fundamentó en estos favores que otorgaba, sino también en el hecho de que fue objeto de rivalidades y envidias por parte de las villas cercanas (Lizana, 1995). ${ }^{5}$ Con los años, a esta dinámica se sumaron otras discusiones relacionadas con la importancia de los milagros y la relevancia que había cobrado dicha devoción que durante casi todo el virreinato se mantuvo bajo la custodia de la orden franciscana.

\footnotetext{
${ }^{4}$ Para saber más detalles sobre la imagen de Nuestra Señora de la Natividad llevada a Mérida junto con la Inmaculada de Izamal, se puede consultar el texto de Francisco Vázquez (1944).

${ }^{5}$ Lizana explica que Landa, además de esta efigie, manda construir otra de Nuestra Señora de la Natividad, imagen que los franciscanos de Mérida deciden conservar en el convento de San Francisco de dicha ciudad. Este acontecimiento conllevó a que los vecinos de Valladolid se sintieran relegados en importancia, por lo que alegaron que la otra imagen no debía quedarse en un pueblo de indios, sino que debía reubicarse en una Villa de españoles, como era la de ellos.
} 
Muchos fueron los factores que influyeron en su auge, pero dos aspectos son los que sobresalieron: primero, durante tiempos prehispánicos, en esta ciudad existió un antiguo centro de peregrinación, elemento que muy posiblemente permitió la continuidad de prácticas religiosas desde inicios de la colonia, por parte de la población indígena de la zona y regiones aledañas. En segunda instancia, la majestuosidad del conjunto religioso cuya edificación, comenzada en 1553, constituyó una prueba de la ambición constructiva de los franciscanos, quienes concibieron a través de su arquitectura un símbolo de la nueva fe, edificada de manera simbólica, dramática y literalmente sobre las ruinas de las antiguas creencias (Bretos, 1992).

Aunque la tradición popular afirma que desde la llegada de la escultura de la Virgen el convento fue considerado santuario por las numerosas peregrinaciones que anualmente recibía desde finales del siglo XVI, fue sin duda en 1648 cuando se declaró a este sitio como baluarte devocional de la provincia de Yucatán, debido a la intervención de la Inmaculada Concepción de Izamal, para erradicar la epidemia de fiebre amarilla que había asolado la capital y numerosas poblaciones de la región. Al dar muestras de ser una gran intermediaria, los pobladores la consideraron como la imagen más milagrosa de la provincia, siendo éste el primer acto con el que la Virgen izamaleña afirmaría su importancia y poder al ser nombrada Reina y Patrona de Yucatán.

En el transcurso del siglo XVII, los continuos actos de fe llevaron a la construcción de una historia devocional rica en milagros y tradiciones, alejada de las imágenes aparicionistas que en ese momento abundaban en el territorio de la Nueva España. Pronto, la Virgen Inmaculada de Izamal se convirtió en un icono alrededor del cual se manejaron relaciones de poder político, religioso, socioeconómico y simbólico, tanto para los regulares como para los grupos mayas de la península de Yucatán (Medina y Quiñones, 2006).

Sin embargo, para consternación de sus devotos, la milagrosa imagen quedó reducida a cenizas tras un incendio acaecido en el viernes santo de 1829, dejando al pueblo desolado ante tan lamentable pérdida. Gracias a un documento denominado Diligencias practicadas 
a consecuencia del incendio acaecido en la iglesia parroquial de Izamal, fechado pocos días después del siniestro, tenemos noticia de que la respuesta del gobierno eclesiástico del obispado de Yucatán fue rápida, al destinar dinero para reponer la imagen con "otra de igual o mejor escultura” que la que se había perdido aquella madrugada fatídica; a la par que pedían a la feligresía que buscase consuelo en la Virgen María, enfatizando que sólo se había perdido el receptáculo (AGN, 1829, BN, vol. 157, exp. 7: 28).

Pese a la sugerencia del obispado, cuenta la tradición oral que la población peninsular pronto se dio a la tarea de encontrar una digna sustituta. No buscaban remplazarla con otra imagen, su deseo iba más allá de la materialidad de una simple escultura: ¿qué mejor que sustituirla por su hermana?, ya que ¿quién entendería mejor que ella el dolor de su pueblo y aceptaría prestarle su cuerpo a la Madre de Izamal para que le siguieran presentando sus respetos?

Así, el pueblo yucateco comenzó la búsqueda de la segunda imagen llevada por Diego de Landa a Mérida, considerada como la hermana de la original, que fue encargada y tallada al mismo tiempo, cuyo destino había sido el convento grande de San Francisco de Mérida, y que para esas fechas se encontraba en manos de doña Narcisa de la Cámara, quien la había heredado de su abuela tercera que, se cree, la tenía en su posesión desde 1700 (González, 1999). ${ }^{6}$ Una efigie que permitió que el pueblo yucateco pudiera continuar la devoción, organizando festejos, peregrinaciones y procesiones tres veces al ańo.

Con este acto se ratificó que para los fieles de Mama Linda lo importante no era la antigüedad de la escultura sino la devoción, que gracias a la imagen trasladada desde Mérida se logró perpetuar bajo

\footnotetext{
${ }^{6}$ Aunque existen numerosas interrogantes respecto a que si la imagen que conservaba en su poder la señora Narcisa de la Cámara era en realidad la segunda pieza escultórica llevada por Diego de Landa en 1560, con advocación de Nuestra Señora de la Natividad, no es la finalidad de este artículo entrar en esa discusión, por lo que me basaré estrictamente en lo que dicta la tradición oral que sustenta el hecho de que sí se trataba de la hermana de la primera escultura que se depositó en Izamal. Ahora bien, hay que hacer notar que en caso de haberse tratado de esa imagen de la Natividad, la escultura tuvo que ser modificada, quitándole al Niño Jesús de los brazos y juntándole las manos, para dejarla en posición orante como suele representarse a la Inmaculada Concepción, advocación de la efigie izamaleña.
} 
el precepto de que el sentido simbólico e identitario que provoca el culto es más fuerte que el receptáculo en sí mismo. Un hecho que suscitó el establecimiento de un símbolo de larga duración que puede perderse y sustituirse, confirmando de esta manera una de las prácticas religiosas más significativas de la región y la más antigua de la península de Yucatán.

\section{Los rostros de la Virgen. La tradición en la historia de Mama Linda}

Cuando analizamos la historia de la Virgen de Izamal, salta a la vista que existe una gran discordancia entre los datos históricos y lo establecido por la tradición oral, denominada por los pobladores de la región "tradición yucateca". ' Las narraciones transmitidas de una generación a otra permiten comprender los vacíos que hay en torno a esta importante imagen religiosa, las cuales se entienden como verdades incuestionables; existen dos tradiciones, a saber: 1) la que menciona que Diego de Landa

\footnotetext{
${ }^{7}$ Desde que inicié mi trabajo de campo en Yucatán (2006) hasta la fecha, he podido notar que los pobladores de esta región denominan "tradición yucateca" a una serie de narraciones que tienen como finalidad dar explicación o llenar vacíos existentes de la historia regional. En específico, en Izamal, son las que hacen referencia a la procedencia de su Virgen y la relación de ésta con Diego de Landa, dando por sentado que al ser un testimonio que se pasa de generación a generación es verdadera e incuestionable.

No se conoce con certeza el origen del término "tradición yucateca", pero bien pudo tener su inicio tras el siglo XIX, cuando numerosos literatos e historiadores ilustrados yucatecos buscaron reconstruir la grandeza del pasado prehispánico y la historia de Yucatán tras el dominio español, por lo que se dio pie a la conformación de la idea de la "yucataneidad" o lo que es yucateco y diferente de los otros. El especialista en arte, Heinrich Berlin (1952), empleó este concepto en su texto Historia de la imaginería colonial en Guatemala, cuando se refiere a la tradición oral que dicta que la segunda imagen llevada por Diego de Landa a Yucatán, y que sustituyó a la escultura de la Virgen de Izamal original, estaba en manos de una señora particular que la donó a la Iglesia, para continuar la devoción. Recientemente es un tema que ha sido analizado desde diferentes perspectivas por investigadores como Steffan Igor Ayora Díaz y Gabriela Vargas Cetina (2010), quienes coordinaron una serie de artículos compilados en el libro: Representaciones culturales: imágenes e imaginación de lo yucateco.

No obstante, es necesario profundizar en este concepto y dedicarle un texto propio, ya que podría acercarnos más a la forma en que los pueblos entienden sus tradiciones y reconstruyen su pasado, mas como no es la finalidad del presente escrito sólo me limitaré a dejar constancia del mismo, con la intención de que posteriormente pueda trabajarse en profundidad.
} 
llevó a Yucatán dos imágenes marianas, siendo además el responsable de comenzar el culto de la que fue destinada a Izamal; ${ }^{8}$ y 2) la imagen que se resguarda actualmente en el templo de Izamal es la hermana de la primera imagen que se perdió en el incendio del siglo XIX, por lo que se trata de la antigua Virgen de la Natividad, llevada por Landa a Mérida en 1560, que fue modificada para sustituir a la izamaleña. ${ }^{9}$

Aunque el traslado de ambas imágenes a Yucatán por parte del franciscano tiene su fundamento en los relatos de las crónicas de Bernardo de Lizana y Francisco Vázquez, lo que causa muchas dudas es el hecho de que la escultura que actualmente se resguarda en el convento izamaleño dista mucho de ser una talla guatemalteca del siglo XVI. Entonces, ¿a qué responde esta "tradición yucateca"?, ¿es un mecanismo creado para continuar este culto tan importante en la vida sociocultural y política de la región, o acaso una forma de resistencia al cambio?

La respuesta pude hallarla al analizar una de las tradiciones orales más importantes para los feligreses: a lo largo del año, Mama Linda presenta tres caras distintas. Así, el primer rostro se puede observar en el mes de mayo, cuando los devotos la describen como un nińa que está entrando a la adolescencia, con un gesto en la cara que resulta grácil, dulce, tierno y sonriente; se trata de la Virgen Niña que aún va

\footnotetext{
${ }^{8}$ Sobre su participación en el culto no hablaré en el presente artículo, dado que existe una discusión al respecto en un trabajo previo. Para conocer más se puede consultar Bertha Pascacio Guillén, "Mama Linda": Reina y patrona de Yucatán. Análisis histórico de una imagen de culto (2013).

${ }^{9}$ A nivel artístico, esta "hermandad" entre las imágenes puede inferirse a partir del hecho de que fueron talladas a la par, por el mismo artífice; aspecto que hace referencia tanto a la autoría como a que fueron manufacturadas dentro de una temporalidad común y que provenían de un mismo taller. Sin embargo, en el área maya, el parentesco entre las imágenes devocionales puede estar sujeto al hecho de que comparten una misma génesis histórica, un territorio devocional e incluso por tener una leyenda o mito que establece lazos entre ellas. Para conocer más al respecto, se pueden consultar las obras de Francisco Fernández Repetto y Genny Negroe, Izamal festivo (2006); Mario Humberto Ruz, "La familia divina. Imaginario hagiográfico en el mundo maya" (2006); Félix Baéz-Jorge, La parentela de María: cultos marianos, sincretismo e identidades nacionales en Latinoamérica (1999); Alfonso Villa Rojas, Los elegidos de Dios (1992); Calixta Guiteras Holmes, Los peligros del alma (1996); Victoria Reifler Bricker, El cristo indigena, el rey nativo (1989); Juan R. Bastarrachea Manzano, Organización social y de parentesco entre los mayas peninsulares (1970), entre otros.
} 
a convertirse en mujer, cuyas facciones todavía no se han endurecido ni madurado.

Para agosto, ya se le describe como una mujer que acaba de entrar en la etapa de madurez; sus facciones la hacen lucir mayor, reflejando que han pasado los años en ella y que está lista para ser esposa y madre; es el periodo en que su cuerpo físico, especialmente su rostro, marca que la juventud ha llegado y los años infantiles han quedado atrás; se trata de la Virgen Joven. El tercer rostro, para los devotos, se hace patente en diciembre, durante su festividad principal, donde luce ya como una mujer que ha sido madre, ya madura, con un gesto cordial pero sensato, signo de que ha obtenido experiencia y sabe lo que implica la maternidad, puesto que ya dio a luz al hijo de Dios, convirtiéndose así, ante los ojos de sus fieles, en la Virgen Madre.

De esta forma, para los devotos, la Virgen no sólo vive los estadíos de una mujer: niñez, juventud y adultez, sino que también manifiesta estas etapas en su rostro, que a lo largo del año va cambiando; las fotografías, según dicen ellos, lo demuestran. Siendo interesante además que durante la fase de adultez, durante su maternidad, su historia se une a otra leyenda de gran valía para su pueblo: la Virgen que está en la iglesia, la traída de Mérida, cambia el cuerpo con su hermana, la de Izamal, para que le festejen; así, la escultura se vuelve un mero recipiente que recibe el "alma" del icono original y vuelve a ser Mama Linda, la que llegó a la vida de los yucatecos en el siglo XVI.

Si analizamos estas leyendas y cotejamos la información con el hecho de que al examinar las diversas litografías, estampas, pinturas y fotografías de la Virgen a lo largo de su existencia, encontramos grandes diferencias que nos permiten establecer la existencia de tres esculturas que han ostentado el título de María de Izamal, tenemos entonces que cada uno de los rostros que describen los feligreses corresponde a cada una de las esculturas que han estado en el santuario ostentando dicho título.

Tenemos idea de cómo fue la primera escultura con advocación de Inmaculada Concepción que llegó a Izamal en 1560, gracias a una vera efigie, fechada en 13 de julio de 1769 , cuya procedencia es desconocida y que actualmente se encuentra en la pinacoteca Juan Gamboa Guzmán 
de la ciudad de Mérida, Yucatán, como se puede ver en la Figura 1 que aparece a continuación.

En el óleo se puede observar una Virgen ampona, ricamente ataviada con un lujoso vestido de color verde oscuro, decorado con ricos broches de piedras preciosas con forma de flor; ostenta además festones de perlas, que le proporcionan lucimiento y simetría al conjunto. Complementa su atuendo un manto de la misma tonalidad, finamente decorado con pequeñas flores y un galón que también muestra piedras preciosas.

Figura 1. Vera efigie de la Virgen de Izamal. Pintura al óleo. Autor anónimo, 1769. Pinacoteca Juan Gamboa Guzmán, Mérida, Yucatán

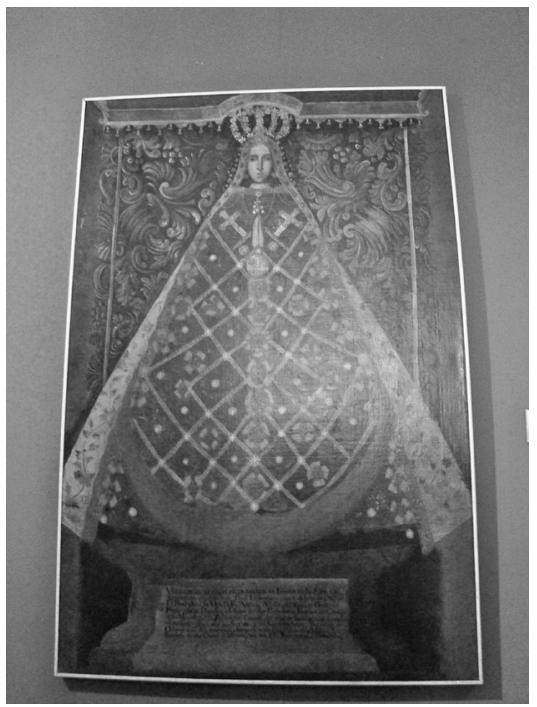

Fuente: fotografía de Bertha Pascacio Guillén.

Por las características de su indumentaria, posiblemente se trata del regalo llevado en 1647 por fray Antonio de Ramírez tras su viaje a España, que se dice era: “[...] un vestido riquísimo, que se le ponen en las principales festividades[...]” (López, 1957: 720). La escultura está engalanada además con aretes y cuentas de perlas; un broche de rubí, dos cruces y tres esferas también de perlas, así como una rica corona real adornada con piedras preciosas. ${ }^{10}$

10 "Muchas han sido, y son, las Vírgenes veneradas en México y casi todas fueron 
La imagen, en actitud orante, con las manos juntas tal como suele representarse a la Inmaculada Concepción, está cubierta casi en su totalidad por la vestimenta, que sólo deja ver sus manos y el pequeño rostro ovalado. Su mirada la dirige hacia el frente en un gesto sobrio y majestuoso; sus ojos alargados se enfatizan por la rectitud de la nariz, delimitada desde el nacimiento de las cejas; destaca su menuda boca enmarcada por la pequeńa quijada; elementos que hacen que sus facciones se muestren suaves e infantiles. Destacando sobre todo la policromía del rostro y manos, que es algo pálida.

Esta escultura es la que describe Diego López Cogolludo en su Historia de Yucatán, publicada en 1688, donde enfatiza que se trata de una imagen de altura de cinco cuartas y seis dedos, de rostro majestuoso y grave de color blanco pálido, con las manos juntas sobre el pecho y levantadas (López, 1957). Pese a que originalmente tenía vestido tallado y estofado, tras su intervención en 1648, para erradicar las numerosas calamidades y la epidemia de fiebre amarilla, recibió muchas joyas y dones, por lo que el padre guardián de Izamal, en aquellas fechas fray Antonio Ramírez, mandó hacer en España un vestido riquísimo que se le colocaba a la imagen en sus festividades principales (López, 1957); situación que le hizo ganarse el sobrenombre de "Niña opalentísima" (Novena..., 1824: 15-16).

Tras el incendio de 1829, la segunda imagen que ostentó el título fue la de la Virgen de la Natividad, originalmente destinada desde su llegada al convento de Mérida, la cual como dicta la tradición sustituyó a la efigie izamaleña. Por el tipo de advocación, tuvo que ser modificada para convertirla en Inmaculada, quitándole al Niño Jesús de los brazos y cambiando la postura de éstos para dejarlos en posición orante, como suele representarse a la Purísima Concepción.

dueñas en una época de ricos tesoros en alhajas; prueba de ello son los poquísimos que aún quedan, pero es sobre todo en los cuadros donde vemos a Nuestra Señora cubierta de perlas y diamantes. Nuestra Señora de la Concepción de Izamal en el remoto Yucatán, está pintada con un vestido bordado con festones de perlas y muy alhajada. [...] y que sus muchas y ricas joyas se le dieron en Mérida en 1648 después de una epidemia por los milagros obrados, tanto que Alejandro VII e Inocencio IX la reconocieron como patrona de este pueblo. En el siglo XVIII los reyes de España le regalaron una corona que fue robada en 1888 . Ahora lleva una moderna y no conserva ninguna de sus alhajas" (Martínez, 1973: 62). 
Fig. 2. La Santísima Virgen de Ysamal (sic). Litografía. Autor anónimo, s. XIX. Museo del convento de San Antonio de Padua, Izamal, Yucatán

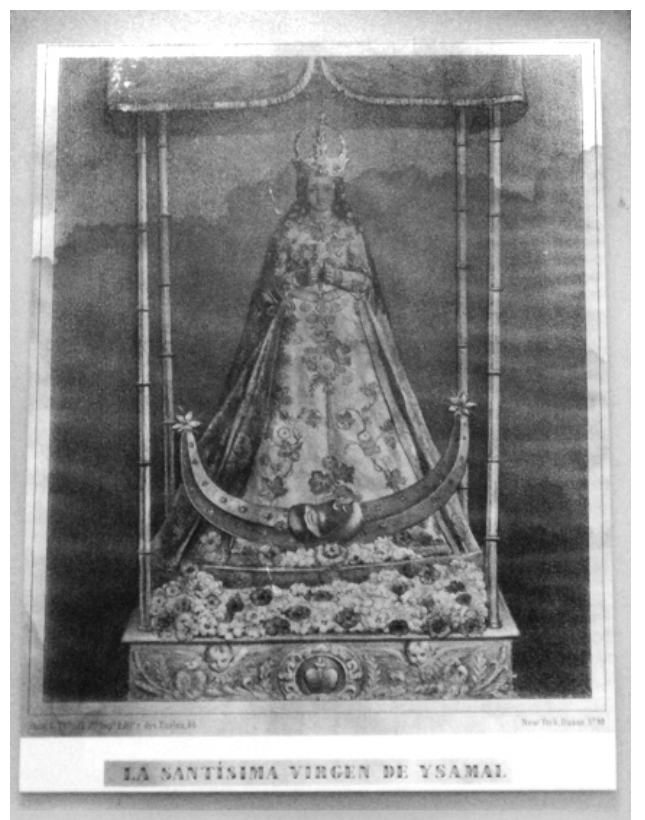

Fuente: fotografía de Bertha Pascacio Guillén.

Al respecto, comenta Heinrich Berlin (1952), que de haberse intervenido la imagen, ésta sufrió una restauración radical para convertirla en Inmaculada Concepción. Antonio Gallo, contestando a dicho autor respecto al cambio que padeció la efigie y en defensa de ésta, menciona que:

La dificultad que pone Berlin de tratarse — si fuera realmente la segunda imagen mandada por Aguirre a Izamal— de una Virgen del Nacimiento, no nos parece definitiva. Estas Vírgenes de Nacimiento podrían transformarse fácilmente en una Inmaculada como la que se contempla hoy en día. [...] Su cara graciosa y sus manos secas y estilizadas podrían confirmar una atribución manierista (Gallo, 1979: 76). 
Existen ciertos rasgos que nos permiten establecer dicha intervención: la rigidez en su posición, especialmente en el área de los brazos; el hecho de portar un cinto, que es el símbolo empleado para representar la maternidad de María y uno de los elementos característicos de la advocación de la Natividad. Así como las similitudes de la talla del rostro que permite asociarla con una efigie antigua de origen guatemalteco; por lo que bien pudo tratarse de la segunda pieza encargada por Landa a fray Juan de Aguirre.

Tenemos entonces, gracias a una litografía realizada por L. Turgis le Jeune, fechada entre 1845-1850, la referencia de cómo fue esta segunda pieza de imaginería. ${ }^{11}$ En ella se puede observar una talla de bulto, dispuesta completamente de manera frontal. De rostro delicado y de rasgos finos; porta corona real de plata sobre la cabeza, cubierta por un manto adornado con diminutas flores.

En el cuello tiene un broche a manera de relicario, mientras su vestido está ricamente adornado por flores y guindas a base de hojas de malta y cardos marianos. Lo que más llama la atención en esta imagen es el escorzo de los brazos, que se nota fueron modificados para colocarlos en posición orante como se suele representar a la Inmaculada, no logrando disponer las manos hacia arriba, por lo que mantiene en general una postura rígida, forzada.

Presenta además la luna en cuarto menguante propia de esta advocación, con rostro antropomorfo y decorada con piedras preciosas, elemento que no aparece en la pieza de imaginería. La Virgen se posa sobre una peana circular, ricamente adornada con flores, cubierta además por un palio de plata y un baldaquín sobrio.

Al comparar esta pieza con la vera efigie de la primera escultura que ostentó el título encontré algunos elementos afines, especialmente en lo que al tratamiento del rostro se refiere, notando solamente que la segunda imagen es un tanto más fina en sus facciones, lo que nos acerca a las descripciones realizadas por Diego López Cogolludo y Francisco de Florencia.

${ }^{11}$ Quien data y aporta la información respecto a esta litografía es Arturo Taracena en su artículo "Las vírgenes guatemaltecas del obispo Diego de Landa. Reflexiones e iconografías sobre la Virgen de Izamal” (2012). 
Por las características que exhibe la litografía, se puede inferir que se trata de la talla de Nuestra Señora de la Natividad, llevada por Landa a Mérida. Ello, teniendo presente que en la gran mayoría de las imágenes de esta advocación, así como en los otros títulos donde la Virgen lleva al Niño Jesús en brazos, es muy común que se le represente de pie, con el rostro hacia el frente, los brazos sosteniendo al Niño o, en su defecto, con un brazo hacia el frente y el otro sosteniendo a Jesús infante sobre su antebrazo o mano, que son los elementos característicos de dicha iconografía.

Son justamente estas características que la asocian con la posibilidad de ser madre las que probablemente hicieron que los devotos la vieran como una virgen joven, con la madurez suficiente para ser madre y concebir al hijo de Dios; la virgen que ya había abandonado la infancia y abrazado la madurez.

Años más tarde, la nueva escultura recibiría como prueba de adopción devocional un regalo muy especial, al ser: "[...] honrada con la corona que los Reyes de España mandaron durante el siglo XVIII, misma que fue robada en 1888; posteriormente, una moderna corona la honró de nuevo, colocándosela don Crescencio Carrillo y Ancona, obispo de Yucatán.[...]" (Dulanto, 1968: 91) ${ }^{12}$. Con este acto y el pasar de los años, la feligresía se recuperó de las heridas ocasionadas por su gran pérdida, surgiendo alrededor de esta nueva efigie toda una serie de leyendas y mitos que reafirmaban la identidad de la misma, a la vez que justificaban su presencia en tan preciado baluarte de fe.

Pero entonces, ¿qué pasó con esta segunda imagen? Cuando se pensaba que el culto había superado todas las adversidades gracias a la presencia de esta nueva escultura, la devoción a la Virgen izamaleña pasaría otras pruebas. Se presentaron nuevos infortunios que impedirían la recuperación vertiginosa de su antiguo esplendor, esto como consecuencia de los diversos conflictos que se vivieron en la península yucateca en las décadas posteriores: la independencia de Yucatán de la corona española, la guerra de castas, la entrada en vigor

\footnotetext{
${ }_{12}$ Para reponerla, el obispo Crescencio Carrillo y Ancona conforma una comisión destinada a recolectar donativos, de forma que se le manda hacer una pieza trabajada en Europa, a la usanza de la pérdida, misma que le fue colocada el 2 de febrero de 1890.
} 
de las Leyes de Reforma y, por último, la separación de Campeche (González, 1999).

De estos eventos, el que sin duda marcó un parteaguas en la ideología peninsular fue la denominada Guerra de Castas, que abarcó de 1846 a $1910 .{ }^{13}$ Dentro de esta contienda social, Izamal jugó un papel activo, especialmente durante la primera década, debido a que los mestizos y criollos encabezados por José del Carmen Bello la tomaron en múltiples ocasiones como sede y defensa:

[...] Izamal es una plaza verdaderamente militar, sobremanera fuerte, porque á más del elevado atrio parroquial y su pórtico que constituye una fortaleza, existen todas las demás colinas artificiales, que no solo dan á la ciudad un carácter de majestad histórica, sino que con mil hombres y la artillería que allí había mandado colocar el General en jefe desde Mérida, se podía defender perfectamente contra la muchedumbre de indios que le asediaba [...] (Carrillo, 1883: 149-150).

El 20 de mayo de 1848, los mayas comandados por su líder Cecilio Chi cercaron la ciudad de Izamal, esperando un gran ataque por parte de los indígenas que los tenían acorralados y para evitar problemas mayores, los soldados hicieron abandonar la población el 28 de ese mismo mes. Los rebeldes entraron a la ciudad, permaneciendo en ella sólo un momento; de este hecho se tiene el siguiente testimonio: "Entramos,

${ }^{13}$ La llamada Guerra de Castas se caracterizó por ser un movimiento social de los mayas en contra de los mestizos y criollos, que duró más de cincuenta años, en pugna por recuperar las tierras y riquezas perdidas durante la conquista espańola. El elemento de unión fue el núcleo religioso, que al no ser sofocado produjo al paso del tiempo una nueva religión, con su propia iglesia, credo y un culto muy peculiar que atrapó a casi toda la población indígena de la región; una religión que se formaría alrededor de las cruces parlantes. Tuvo su origen en diversos factores, pero se podría considerar como el principal el antiguo odio que los mayas sentían hacia los forasteros o $d z u l e s$, por la explotación de la que fueron víctimas los naturales por parte de los encomenderos. Sumado a ello, se encontraba también: la opresión de la que fueron objeto por parte de la Iglesia y del Estado, el reclutamiento indígena a manos de los ladinos, quienes recurrentemente los utilizaron en sus batallas políticas, así como la contribución económica que aumentó con la presencia de los clérigos seculares, quienes elevaron las obvenciones que pagaban los indígenas por recibir los sacramentos (Reifler, 1989). 
señor, le dijo, pusimos a la Virgen frente al Oriente, le colocamos unas cuantas monedas por ofrenda, imploramos su protección, y luego nos retiramos trayendo cada cual lo que pudo recoger" (Peniche, 1980: 74).

El caso de Izamal fue único, debido a que los saqueos y el incendio fueron de menor alcance que los que se ejecutaron en otras poblaciones:

Respetuosos del lugar para asombro de las fuerzas del capitán Lozano Ruz y del teniente coronel Tomás Peniche, quienes pudieron recuperar la plaza sin ninguna resistencia. Se ha pensado que este retiro de las fuerzas rebeldes se debió al inicio de la época de lluvias, dándose un repliegue general ante la necesidad de sembrar sus milpas y sementeras (González, 1999: 60-61).

¿Será esto cierto o sus acciones correspondieron al hecho de que dicha ciudad era el baluarte de la Virgen a quien durante más de dos siglos los mayas habían rendido devoción y respeto? Recordemos que esta imagen era considerada la madre de todos sin excepción de raza o color, que constantemente realizaba múltiples milagros a sus devotos; además de que muchos de los mayas rebeldes gustaban asistir a sus festividades y peregrinaciones, ya que la consideraban su patrona y abogada.

$\mathrm{Al}$ paso de los años, Izamal siguió fungiendo como uno de los puntos principales de defensa para el gobierno yucateco durante los continuos ataques acaecidos por manos de los mayas rebeldes. En 1849, en un intento de que el pueblo se arraigase en la fe católica, el obispo José María Guerra escribió al Papa Pío IX para expresarle: “[...] que se unía a través del voto y oraciones de toda su diócesis a la intención de declarar el dogma de la Inmaculada Concepción” (González, 1999: 60).

Pese a los esfuerzos del obispo por impulsar el dogma mariano, la declaración llegó hasta el 8 de diciembre de 1854, mediante la bula Ineffabilis Deus, que dio la definición dogmática de la Inmaculada Concepción de la Virgen María, por lo que los yucatecos que la tenían como Reina, Patrona y Señora especial de Yucatán, celebraron el triunfo con gran regocijo (Carrillo, 1878).

Un reconocimiento que el obispo firmó sobre el altar de Nuestra Señora de Izamal, como símbolo de la devoción y respeto a tan 
venerada imagen (Carrillo, 1895: 1046). Sin embargo, en 1857, tras el establecimiento de la Constitución General, la Iglesia en México comenzó a sufrir una gran persecución consecuencia de la Reforma anticatólica, que tenía como finalidad la expropiación de los bienes eclesiásticos, así como la supresión y secularización de la orden franciscana, por lo que muchas de las congregaciones fueron despojadas de sus bienes y capitales (Carrillo, 1895).

Izamal no fue la excepción, pero poco se sabe de lo ocurrido en esta población. La siguiente noticia que se tuvo fue en 1859, cuando se promulgó el denominado Plan de Izamal con el que el coronel Pedro Acereto desconoció el gobierno de Liborio Irigoyen, trasladando el Ejecutivo a dicha entidad durante 1860. A partir de estas fechas y hasta 1863, esta población sería la protagonista de numerosas luchas armadas que tenían como objetivo desestabilizar el gobierno estatal de Irigoyen.

En 1861, por decreto gubernamental se despojó a los regulares del seminario de la Universidad Pontificia (Carrillo, 1895): "Redujeron al interior de los templos las imágenes sagradas y los actos del culto. Prohibieron las procesiones, y obligaron, en fin, á los sacerdotes a despojarse de sus vestiduras peculiares y distintivos eclesiásticos" (Carrillo, 1895: 1049). Un año después se decretó la supresión de los Cabildos catedralicios y la expulsión de los pocos misioneros que quedaban en la península yucateca (Carrillo, 1883):

[...] Así, en la política de hecho, la Augusta Virgen María no es ya la Patrona y la Reina de nuestro pueblo, porque el Estado rompió los vínculos de unión con la Iglesia, y redujo el culto católico, el culto popular, el culto histórico, el culto nacional, a nivel de falsos cultos, de los cultos extraños, relegándolo á la condición de privado y doméstico, según lo que en la escuela liberal se llama libertad de cultos y libertad de conciencia.[...] (Carrillo, 1878: 69).

¿Será acaso que, en este tiempo de gran convulsión social, la Virgen izamaleña se perdió nuevamente? De ser así, en 1875, cuando el entonces obispo Leandro Rodríguez de la Gala junto con el presbítero Crescencio Carrillo y Ancona buscaron impulsar el culto a Nuestra 
Señora de Yucatán hallaron que Mama Linda, la imagen de mayor devoción en esta región, no se encontraba en su santuario.

Ante el vacío que hay sobre qué sucedió con esta segunda escultura izamaleña, me di a la tarea de buscar elementos que permitiesen reconstruir su historia, hallando la narración de un viajero que resulta muy ilustrativa:

De pronto oi algunos disparos y gritos que parecían acercarse a la casa vivienda. Estando cerca del territorio de los indios bravos, por un momento pensé en una de sus incursiones. Inmediato salí, feliz de tener la ocasión de empuñar mi revólver, y vi a un indio muy alto, llevando una caja sobre la espalda... Alrededor de él, como 15 de sus congéneres bailaban, saltaban, gritaban descargando sus fusiles, mientras que el último de la fila tenía una botella de aguardiente sobre la nariz.

-¿Qué es eso? -pregunté asombrado.

-Es la Mama Linda.

-Pero, ¿qué es eso de la Mama Linda?

Tuve la explicación. La Mama Linda, la gentil Mama Linda es la Virgen. Como en este país de separación de la Iglesia y del Estado, no todos los pueblos pueden tener una estatua, entonces la Mama Linda viaja un mes por aquí, dos meses por allá. [...] la procesión escaló las anchas escaleras de la vieja pirámide, en la cima de la cual está construida la pequeńa iglesia de Aké, que tomó el lugar de un antiguo templo de Kukulkán; descansamos ahí durante una media hora. La caja se abrió, y la Mama Linda recibió la adoración de todos. Nada era tan curioso como ver a los bebés indígenas desnudos, levantados por las mujeres, besar maravillados el vestido de adornos de oro de la pequeña madona. Al poco tiempo, la Virgen viajera volvía a partir con su tumultuosa escolta (Chambón, 1892: 42).

Este texto publicado en 1892 corresponde a un francés llamado Ludovic Chambon, cuya fecha precisa de su viaje a Yucatán no se conoce, pero por lo que anota en su libro acerca de las pérdidas en la población 
yucateca a causa del vómito negro, el estado anticlerical y su encuentro con Thompson, pudo haberlo escrito entre 1885 y $1890 . .^{14}$

Su relato nos brinda un poco de luz respecto a las diferencias entre las imágenes presentadas durante la última mitad del siglo XIX. Él explica que la escultura mariana que pudo observar era llevada en una caja por un indio muy alto, posiblemente alguien que superaba los $165 \mathrm{~cm} ;{ }^{15}$ si consideramos que se trataba de la segunda escultura que encargó Landa en Guatemala, la cual según las fuentes era idéntica a la del Coro y a la primera Inmaculada de Izamal, tendríamos que se trataba de una efigie que medía aproximadamente $115 \mathrm{~cm}$, de tal forma que podía ser transportada con facilidad por un sujeto con las características antes descritas.

Para los mayas, las imágenes religiosas, en especial las de la Virgen María, son de suma importancia dentro de su cosmovisión. No se trataba de simples esculturas que fueron empleadas durante su evangelización; para ellos, se convirtieron en el centro rector a través de las cuales se organizaba su vida, relaciones sociales, comerciales y políticas. De esta forma, el poseer un icono de tal envergadura significó haber recuperado el control y poder de la región.

Tomando en consideración estos aspectos, no sería extraño que incluso ellos mismos hubieran sacado de su santuario a la Virgen izamaleña, para llevarla a visitar las poblaciones durante la restricción de cultos religiosos públicos ordenados por las Leyes de Reforma, buscando con eso evitar futuros males en sus comunidades. ${ }^{16}$ Lo que

${ }^{14}$ Edward Herbert Thompson, célebre arqueólogo y diplomático estadounidense, quien inspirado por los libros de John L. Stephens llegó en 1885 a Yucatán con la intención de estudiar la historia y civilización de los mayas, pasando la mayor parte de su vida en esta región.

15 Respecto a la estatura promedio de los diferentes grupos mayas, existen trabajos que nos permiten establecer una idea al respecto, lo cual llevó al establecimiento de la propuesta que se hace en el presente trabajo. Para más información, se pueden consultar los trabajos de Vera Tiesler Blos, "La estatura entre los mayas prehispánicos. Consideraciones bioculturales" (2001); Alfonso Villa Rojas, Los elegidos de Dios...; Morris Steggerda, Maya indians of Yucatán (1941), entre otros.

16 Además hay que recalcar que desde tiempos prehispánicos Aké, junto con Ucí y Cansahcab, eran poblaciones que estaban conectadas por los sacbeob, caminos construidos para mantener una estrecha comunicación con las poblaciones periféricas, a la vez que simbolizaban la importancia política y económica de la ciudad, en este caso 
sí causa curiosidad es que este acontecimiento narrado por Chambón ocurre entre 1885 y 1890, casi siete años después de que Carrillo y Ancona presentara una nueva escultura de la Virgen de Izamal.

Por lo cual, propongo la tesis de que, para las décadas de los 60 y 70 del siglo XIX, Mama Linda fue sacada en diversas ocasiones de su templo con la finalidad de que visitase los pueblos de sus devotos, convirtiéndose en un imagen peregrina. Existen dos razones por las que pudo quedar en manos de los mayas: la primera, porque éstos trataron de evitar su pérdida, como sucedió con la Virgen de Tabí a comienzos de la Guerra de Castas (Reed, 1971); la segunda, porque posiblemente fue entregada por los religiosos que quedaron en la región, a manera de mecanismo de control para evitar el abandono de la fe, bajo la idea de que algún día volverían a recuperar el antiguo esplendor de sus misiones.

En 1876, cuando el presbítero Carrillo y Ancona intentó impulsar de nuevo el culto inmaculista en Yucatán, la Virgen de Izamal estaba perdida o en manos de la sociedad maya que la mantenía en continuas peregrinaciones, negándose a devolverla a los religiosos por considerarla ya como de su propiedad y, por tanto, suponer que debía permanecer bajo su custodia; por ello, el religioso decidió colocar una tercera escultura en el santuario de Izamal, invitando a los feligreses a unirse bajo los preceptos de una Virgen tan importante para la historia regional, nuevamente bajo el cobijo de la Iglesia católica.

Esta tercera imagen es la que actualmente podemos observar en el templo de San Antonio de Padua en Izamal y de la que habla Carrillo en su libro La civilización yucateca o el culto de la Virgen María en Yucatán (1878), texto con el que buscó reactivar la devoción a esta efigie. Se trata de una escultura de bulto, de rostro ovalado con finas facciones que le dan un aire de solemnidad; destaca su ligera papada que sobresale a manera de delicado bulto, así como el mentón que está acentuado por un grácil hoyuelo.

Izamal, que era considerada centro rector de suma importancia para la región norte de la península. 
Figura 3. Izquierda. Nuestra Señora de Izamal (Yucatán). Litografía. (CCA) (R)

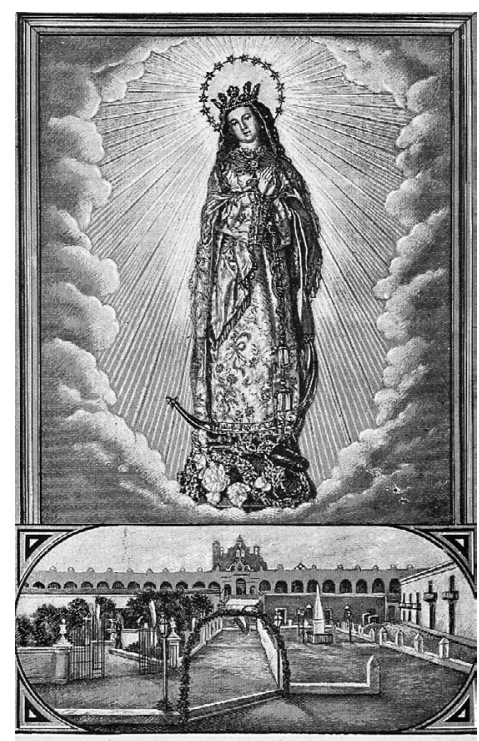

Nutstra Señora de izamal (Yucaláx)

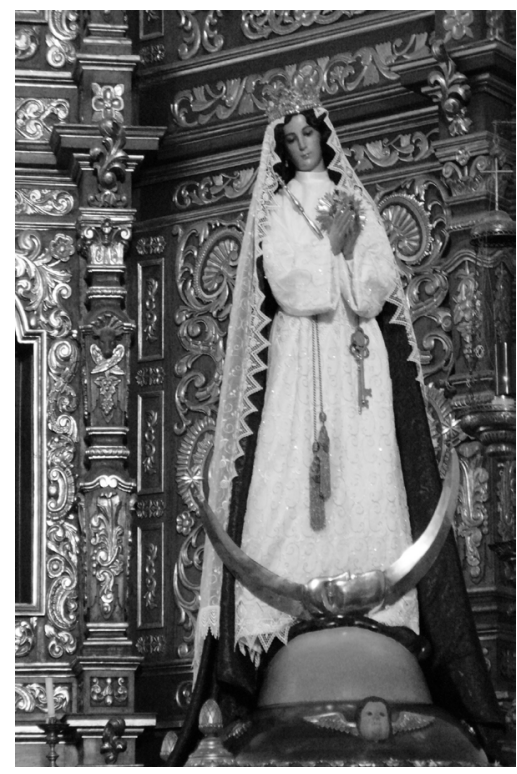

Figura 4. Derecha. Virgen de Izamal. Convento de San Antonio de Padua, Izamal, Yucatán. (BP, 2009).

Su cabeza, inclinada ligeramente hacia la derecha, sigue la curvatura del cuerpo enfatizado por el contrapposto del lado izquierdo, mientras sus manos, en posición orante, se juntan hacia el lado opuesto — siguiendo una sutil línea curva-; presenta, además, los atributos iconográficos con los que suele representarse a la Inmaculada Concepción: corona real, aureola con estrellas, media luna, sierpe pisada a sus pies y globo terráqueo.

Está dispuesta en medio de un rompimiento de gloria, sobre una vista panorámica del santuario de Izamal. Desconozco si se trata de una escultura tallada de bulto redondo policromada y estofada, o si fue hecha para vestir. En especial llama la atención el hecho de que la indumentaria está muy pegada al cuerpo, así como la rigidez de los pliegues y ondulaciones que tratan de asemejar la caída de las telas. 
Va cubierta por un velo que deja ver parte del cabello, mientras su manto está decorado con motivos florales. Porta un relicario y un corazón de plata finamente adornados. Sostiene los extremos de su manto sobre los antebrazos, dejando descubierta la parte central del vestido, mostrando la cinta atada sobre su vientre. Se posa sobre una peana ricamente adornada con flores.

Pese a tratarse de una efigie de la Inmaculada Concepción, su presencia traería consigo múltiples cuestionamientos relacionados con las diferencias que se podían observar en esta pieza con respecto a sus predecesoras.

\section{Cambios y continuidades. Tras los pasos de una tradición}

Con la presencia de una tercera imagen se hizo necesaria la creación de dos mitos, que se han compartido de generación en generación al grado de convertirse en "tradiciones" que validan la imagen que se resguarda actualmente en el convento: a) la Virgen presenta tres rostros distintos a lo largo del año, y b) se trata de la hermana de la Virgen izamaleña, que le ha prestado su cuerpo para que le festejen sus devotos.

La credibilidad de estas argumentaciones tiene su fundamento en el proceso del imago social, que ha permitido la pervivencia de la imagen sacra, adaptándola y moldeando los acontecimientos bajo los preceptos de una "tradición yucateca", misma que le ha proporcionado continuidad con el pasado, ${ }^{17}$ resultando de gran importancia porque de haberse

17 Por imago social podemos entender al prototipo inconsciente de personajes que orienta electivamente la forma en que el sujeto aprehende a los demás; se elabora a partir de las primeras relaciones intersubjetivas reales y fantaseadas con el ambiente familiar; las relaciones del individuo con su ambiente social y familiar. La imago designa la pervivencia imaginaria de alguno de los participantes en aquella situación. Con frecuencia se le define como una representación inconsciente, pero es más que una imagen, un esquema imaginario adquirido, de manera tal que puede objetivarse en sentimientos, conductas e imágenes.

Por otra parte, hago alusión al término 'tradición inventada', propuesto por Eric Hobsbawm, el cual se refiere a todas las tradiciones que han sido construidas, instituidas o que emergen a lo largo de un periodo de tiempo breve y datable, logrando arraigarse con rapidez dentro de una sociedad. "Por tradición inventada debemos entender una serie de prácticas regidas habitualmente por unas normas aceptadas explícita o tácitamente y por un ritual de naturaleza simbólica, que tratan de involucrar a partir de su reiteración constante, determinados valores y normas de comportamiento, lo 
sabido que la efigie considerada durante siglos como la más milagrosa de Yucatán se había perdido nuevamente, habría ocasionado serias consecuencias dentro del pensamiento de los feligreses que ya consideraba el incendio de 1829 como un indicador de futuras desgracias.

En este contexto, el conjunto de "tradiciones inventadas" constituyó un recurso trascendental para dotar de respuestas la presencia de una tercera imagen, permitiendo su aceptación y adaptación, dentro del contexto de un culto antiguo que se negaba a ser olvidado, sobre todo por la importancia económica, social, cultural, política y religiosa que centurias atrás implicó, tanto para los religiosos como para la sociedad. Con el paso del tiempo, la imagen de Izamal se convirtió en un icono producto más que de representaciones heredadas, de posibilidades heredadas de representaciones (Jung, 2002); donde el valor del ideal religioso superó al soporte, perpetuando el culto más allá de las fronteras del objeto que constituyó su punto de partida.

Estas tradiciones, al ser aceptadas por la sociedad yucateca, se convirtieron en un conjunto de convenciones y rutinas que fueron formalizadas con la finalidad de instruir a los nuevos miembros en tales prácticas (Hobsbawm, 2001); se crearon hábitos que poco a poco se fueron interiorizando en la memoria colectiva $y$, por ende, en la psique del individuo, transformándose con el paso del tiempo en un proceso automático, invariable, que permitió hacer frente a cualquier contingencia.

De esta forma, aunque las esculturas que han representado a la Virgen de Izamal guardan notables variaciones en forma y estructura, para los devotos lo importante es que la efigie actual constituye un medio a través del cual ha podido pervivir el culto, argumentando que sólo se trata de un cuerpo diferente que contiene a la misma esencia; por lo que ante la pérdida de la efigie original, el sustituirla no constituyó problema alguno.

La devoción del pueblo asimiló que la esencia o "alma", como ellos le llaman, puede cambiar de cuerpo sin problema alguno, que la

que auténticamente implica un vínculo con el pasado. De hecho, allí es donde es posible, esa continuidad normalmente se intenta establecer con un pasado adecuado. [...] El pasado histórico en el que se inserta la nueva tradición no necesita ser longevo hasta remontarse al origen de los tiempos [...]" (Hobsbawm, 2001: 203-206). Para mayor información respecto a este término, también puede consultarse el texto de Eric Hobsbawm y Terence Ranger (edits.), La invención de la tradición (2002). 
divinidad es eterna pese a los deseos de los hombres. Debido a esto, el culto pudo pervivir ante un evento tan drástico, ya que la respuesta que generó la imagen fue psicológica, ocasionando una emoción en quien la veneraba, quedando fuera de estos límites el valor del soporte, porque lo que "ella producía" era mayor a la importancia o diferencia estética que era percibida a través de los sentidos.

No obstante, esta esencia sólo puede traspasarse a un objeto que guarde cierto vínculo con el original, ya sea que compartan una misma raíz histórica, un territorio devocional o un mito de origen, aspectos que le confieren su carácter y validez dentro de la cosmovisión maya, tal como era el caso de la Virgen de la Natividad que se encontraba en Mérida. En esta sociedad, como muchas otras en el mundo: "Lo que importa es la respuesta, que se basa en la idea de la presencia, no en el hecho de la representación" (Freedberg, 1992: 46). ${ }^{18}$

En la aceptación de la imagen llevada por Carrillo y Ancona podemos apreciar el respaldo de una cultura donde pervive la intención y creencia de que la transferencia de los espíritus es parte esencial de la vida de una imagen; donde la efigie es trascendente en la medida de lo que representa y contiene, mas no por el valor estético que le podamos inferir, en otras palabras: el poder de su respuesta.

Así, la Virgen María, traída por los franciscanos, de carácter noble, protectora y materna, bajo el título de Izamal, se convirtió en un símbolo de larga duración que puede quemarse y sustituirse. Un icono a través del cual se ha logrado perpetuar una devoción cuyo sentido simbólico e identitario ha sido más fuerte que la imagen en sí misma, al permanecer investida de un significado que va más allá del individuo, amalgamando una colectividad alrededor de una fuerza superior, caracterizada por lo que ha tenido de sagrada.

18 “[... Los historiadores del arte dejan a un lado los síntomas del poder de las imágenes cuyas raíces son más profundas que las de la atracción o rechazo estético más o menos anodinos. Nada nos cuesta creer que en las culturas primitivas se considere que las imágenes participan de la vida de aquello que representan o incluso de la vida de otras cosas a las que no representan [...]" (Freedberg, 1992: 50). 


\section{Consideraciones finales}

En Yucatán, las imágenes devocionales no sólo participan de la vida activa del pueblo que las custodia, sino que también son miembros dinámicos que intervienen en los procesos históricos y culturales del mismo. La Virgen de Izamal, desde su llegada a esta pequeña población del oriente de Yucatán, fue la encargada de acercar a los mayas a la devoción de la Madre de Dios, para lo cual fue colocada en la iglesia del convento edificado sobre las antiguas ruinas del santuario precolombino dedicado a Itzam Ná, deidad maya que realizaba milagros relacionados con la salud y la fecundidad, prodigios que pronto asumió la imagen mariana como propios.

Su presencia dio paso a la creación de un culto regional que al poco tiempo permitió el establecimiento del primer santuario de la península yucateca, el cual fue administrado por los franciscanos, quienes emplearon a éste como modelo y eje para la instauración de otras devociones a lo largo de esta geografía peninsular.

La pérdida de la efigie en 1829 significó para los feligreses un mal augurio, por lo que se creó toda una serie de hitos en el imaginario social que llevaron a la búsqueda de un reemplazo digno de su importancia religiosa y social. Implicó, entonces, no sólo la sustitución de una imagen para llenar un vacío en el altar, sino una sustitución que implicaba la existencia de un alma o esencia a la que sólo se le podía otorgar un receptáculo tan especial como lo era ella misma, buscando para sus fines la imagen con la que guardaba un íntimo lazo de parentesco: su hermana gemela.

La existencia de esta hermandad y el vínculo que se conoce conservan los gemelos por compartir el mismo vientre — en este caso haber sido manufacturadas en el mismo sitio, por el mismo escultor y bajo el mismo modelo-, logró solidificar en el imaginario colectivo la posibilidad del "préstamo del cuerpo", que permitiría la pervivencia del alma original, mimetizándose en una sola persona; sin duda alguna, el lazo de parentesco, al igual que sucede entre los humanos, permitió que fuesen arropadas por la sociedad para quien el receptáculo pasó a un segundo plano, siendo más importante el conservar la esencia que en él se contenía. 
Fue precisamente esta respuesta a la pérdida lo que permitió que décadas después, ante el extravío de esta hermana sustituta, se creara nuevamente una tradición oral que permitiese otra vez la pervivencia de la imagen, adaptando y moldeando las diferencias existentes entre las tres efigies mediante un discurso con el cual el pueblo las validaba. En esta ocasión, el imaginario colectivo optó por justificar los cambios en la efigie como parte del crecimiento de la Virgen, la cual al ser un ente vivo, debe atravesar por los estadíos propios de una mujer: nińez, juventud y adultez.

Al pasar de los años, las diferencias entre la segunda imagen y la llevada en el siglo XIX se hicieron imperceptibles, se reactivó el culto y con ello nuevos hábitos alrededor de ésta. Poco a poco se fueron interiorizando en la memoria colectiva, transformándose en un proceso que permitió hacer frente a cualquier contingencia. Se crea con ello un icono de larga duración que puede reinventarse y adaptarse a los cambios que la pátina del tiempo le otorgue.

\section{Bibliografía citada}

Ayora Díaz, Steffan Igor y Gabriela Vargas Cetina (editores), 2010, Representaciones culturales: imágenes e imaginación de lo yucateco, Universidad Autónoma de Yucatán, Mérida, Yucatán.

Báez-Jorge, Félix, 1999, La parentela de María: cultos marianos, sincretismo $e$ identidades nacionales en Latinoamérica, Universidad Veracruzana, Xalapa, Veracruz.

Bastarrachea Manzano, Juan Ramón, 1970, Organización social y de parentesco entre los mayas peninsulares, Tesis de Licenciatura, ENAH, México.

Berlin, Heinrich, 1952, Historia de la imaginería colonial en Guatemala, Editorial del Ministerio de Educación Pública, Guatemala. Bretos, Miguel, 1992, Iglesias de Yucatán, Producción Editorial Dante, Yucatán, México. 
Carrillo y Ancona, Crescencio, 1878, La civilización yucateca o el culto de la Virgen María en Yucatán. Disertación histórico-religiosa sobre el culto de la purisima Virgen entre los yucatecos desde la conquista, y sobre su influencia social hasta nuestros dias, Imprenta de Miguel Espinoza Rendón, Mérida, Yucatán.

Carrillo y Ancona, Crescencio, 1883, Vida del V. Padre fray Manuel Martínez. Célebre franciscano yucateco, ó sea estudio histórico sobre la extinción de la orden franciscana en Yucatán y sobre sus consecuencias, Gamboa Guzmán y Hermano, Impresoreseditores, Mérida, Yucatán.

Carrillo y Ancona, Crescencio, 1895, El Obispado de Yucatán. Historia de su fundación y de sus obispos desde el siglo XVI hasta el XIX, Tomo 2, Imprenta de Ricardo B. Caballero, Mérida, Yucatán.

Cepeda, Félix Alejandro, 1905, América mariana ó sea Historia compendiada de las imágenes de la santísima Virgen más veneradas en el Nuevo Mundo, Tomo 1, Imprenta de José Sáenz Moneo, México.

Chambon, Ludovic, 1892, Viaje a un México pintoresco. Yucatán, Campeche y Chiapas, Joaquín Porrúa, S.A. de C.V., México.

Dulanto, Enrique, 1968, "Izamal, santuario mariano del sureste", en Artes de México, año XV, núm. 113, pp. 85-91.

Fernández Repetto, Francisco y Genny Negroe, 2006, Izamal festivo, Instituto de Cultura de Yucatán, Universidad Autónoma de Yucatán, Consejo Nacional de Ciencia y Tecnología, México.

Florencia, Francisco de y Juan A. de Oviedo, 1995, Zodiaco Mariano, Consejo Nacional para la Cultura y las Artes, México.

Freedberg, David, 1992, El poder de las imágenes. Estudios sobre la historia y la teoría de la respuesta, Cátedra, Madrid.

Gallo, Antonio, 1979, Escultura colonial en Guatemala. Evolución estilistica de los siglos XVI-XVII-XVIII, Dirección General de Cultura y Bellas Artes, Guatemala.

González Cicero, Stella Ma., 1999, Nuestra Señora de Izamal. Reina y patrona de Yucatán, Fomento Cultural Banamex, A. C., Mérida, Yucatán.

Guiteras Holmes, Calixta, 1996, Los peligros del alma, Fondo de Cultura Económica, México. 
Hobsbawm, Eric y Terence Ranger (editores), 2002, La invención de la tradición, Editorial Crítica, Barcelona.

Hobsbawm, Eric J., 2001, "Inventando tradiciones", en Historia Social, núm. 40, Fundación del Instituto de Historia Social, Madrid, pp. 203-214.

Jung, Carl, 2002, Los arquetipos y lo inconsciente colectivo, Obra completa, vol. 9/1, Edición de la Fundación C. G. Jung, Editorial Trotta, Madrid.

Lizana, Bernardo de, 1995, Devocionario de Nuestra Señora de Izamal. $Y$ conquista espiritual de Yucatán, Edición facsímil de René Acuña, Universidad Nacional Autónoma de México, México.

López Cogolludo, Diego, 1957, Historia de Yucatán, 2 vol., edición de Ignacio Rubio Mañé, Editorial Academia Literaria, México.

Martínez del Río, Marita, 1973, "Joyas coloniales y románticas", en Artes de México, Alhajas mexicanas, núm. 165, pp. 49-75.

Medina, Martha, Teresa Quiñones, 2006, "Peregrinando por los santuarios de la península de Yucatán”, en Estudios de Cultura Maya, vol. XXVII, Universidad Autónoma de México, México, pp. $165-180$.

Novena de la Sacratisima Virgen de Itzmal. Esto es, a obsequio de la milagrosa imagen de Nuestra Señora, que bajo este nombre se venera en su santuario del pueblo de Itzmal..., 1824, Oficina del Sur, Mérida, Yucatán.

Pascacio Guillén, Bertha M., 2013, "Mama Linda”: Reina y patrona de Yucatán. La virgen de Izamal, análisis histórico de una imagen de culto, Tesis de Maestría en historia del arte, Facultad de Filosofía y Letras, Universidad Nacional Autónoma de México, México, D.F.

Peniche Vallado, Leopoldo, 1980, Promotores e historiadores de la rebelión maya de 1847 en Yucatán, Fondo Editorial de Yucatán, Mérida, Yucatán.

Reed, Nelson, 1971, La guerra de castas de Yucatán, Ediciones Era, México.

Reifler Bricker, Victoria, 1989, El cristo indígena, el rey nativo. Elsustrato histórico de la mitología ritual de los mayas, FCE, México. 
Ruz, Mario Humberto, 2006, "La familia divina. Imaginario hagiográfico en el mundo maya", en Mario Humberto Ruz (editor), De la mano de los sacro. Santos y demonios en el mundo maya, Universidad Nacional Autónoma de México, México.

Scholes, France V. y Eleanor B. Adams, 1938, Don Diego Quijada Alcalde Mayor de Yucatán 1561-1565, Tomo 1, Antigua Librería Robredo de José Porrúa e Hijos, México.

Steggerda, Morris, 1941, Maya Indians of Yucatán, Carnegie Institution of Washington, Washington, D.C.

Taracena, Arturo, 2012, "Las vírgenes guatemaltecas del obispo Diego de Landa. Reflexiones iconográficas sobre la Virgen de Izamal", en Miguel Lisbona Guillén y Antonio de Higuera Bonfil (coordinadores), El vigor de las imágenes. Miradas interdisciplinarias, Universidad Nacional Autónoma de México, Instituto de Investigaciones Antropológicas, Programa de Investigaciones Multidisciplinarias sobre Mesoamérica y el Sureste, Universidad de Quintana Roo, México.

Tiesler Blos, Vera, 2001, "La estatura entre los mayas prehispánicos. Consideraciones bioculturales”, en Estudios de Antropología Biológica, vol. 10, núm. 1, pp. 257-273.

Villa Rojas, Alfonso, 1992, Los elegidos de Dios. Etnografía de los mayas de Quintana Roo, Dirección General de Publicaciones del Consejo Nacional para la Cultura y las Artes, Instituto Nacional Indigenista, México.

Vázquez, Francisco, 1944, Crónica de la Provincia del santísimo nombre de Jesús de Guatemala de la orden de N. Seráfico padre San Francisco en el reino de la Nueva España, Tomo 2, Tip. Nacional, Guatemala.

\section{Documento histórico}

Archivo General de la Nación, 1829, Diligencias practicadas a consecuencia del incendio acaecido en la iglesia parroquial de Izamal. Yucatán, Regio Patronato Indiano, Bienes Nacionales, vol. 157, exp. 7, 28fs. 